\title{
The European Court of Human Rights and Article 18 - An Indicator for the State of Democracy in Europe?
}

\author{
Christiane Schmaltz
}

\section{A. Introduction - An Alarming Tendency}

On 27 July 2019, the Moscow police, following a day of mostly peaceful protests, took more than 1,000 people into custody. One week later, there were again peaceful protests and again hundreds of arrests. The people were taking to the streets because the electoral commission had denied opposition candidates a place on the ballot for the election to Moscow's city council. Allegedly, the signatures the candidates had collected were fake. ${ }^{1}$

It seems likely that most - if not all - of these 1,000 and more arrests were not the result of a reasonable suspicion that the arrested had committed an offence as prescribed by Article 5 of the Convention. Even more, it is obvious that the protestors were detained to prevent them from voicing their support for the opposition candidates. In the words of the European Court of Human Rights in Strasbourg, such a police crackdown on protests as in Moscow will inevitably have a 'chilling effect' ${ }^{2}$ on political expression. It will suppress the activity of individuals taking part in such actions and thereby destroy what is most valuable in a democratic society - free expression and public discourse.

These episodes illustrate the topic of this chapter and lead straight into the heart of the issue - the prohibition to limit rights set forth in the European Convention on Human Rights (ECHR) for any purpose other than those stipulated in the convention. This is enshrined in Article 18 of

1 See Bershidsky, 'Putin reminds Russians he can do suppression', Bloomberg L.P., 29 July 2019, https://www.bloombergquint.com/business/moscow-protests-vladimi r-putin-s-suppression-potential; Bigalke, Mit aller Macht, Süddeutsche Zeitung, 28 July 2019, https://www.sueddeutsche.de/politik/russland-mit-aller-macht-1.4542891

2 See ECtHR, Judgment, 15 May 2014, Taranenko $v$ Russia, Application No. 19554/05, para. 95; ECtHR, Judgment (GC), 2 February 2017, Navalnyy v Russia, Application No. 29580/12 and 4 more, Joint Partly Dissenting Opinion of Judges López Guerra, Keller and Pastor Vilanove, para. 4. 
the ECHR. The provision has achieved an inglorious and rather alarming prominence since the Strasbourg Court has begun to repeatedly hand down judgments finding a violation of this article.

There are many aspects relevant to Article 18 ECHR. This chapter will provide a brief introduction to the provision (B.) including an overview of the recent jurisprudence of the Strasbourg $\operatorname{Court}^{3}$ (C.) and will then outline some thoughts on a somewhat bolder approach to Article 18 ECHR and its application. In doing so, the chapter will draw on ideas already voiced by a number of judges in separate opinions. ${ }^{4}$ The focus of this chapter will be the scope of application of Article 18 ECHR, namely its application in conjunction with Article 6 ECHR (D.), as well as questions of proof (E.). It will conclude with a critique of the practice of the Court to sometimes refrain from a separate examination of the alleged violation of Article 18 ECHR (F.).

As this chapter aims to discuss questions surrounding Article 18, which have in the author's view not yet been - sufficiently - clarified by the Court, it will not address the specific issue of the predominant purpose test established by the Grand Chamber in Merabishvili v. Georgia ${ }^{5}$. This test addresses the question of how to deal with restrictions of rights or freedoms under Article 18 ECHR which are applied both for an ulterior purpose and a purpose prescribed by the Convention ('plurality of purposes'). ${ }^{6}$ In Merabishvili v. Georgia, the Court ruled that in such cases the restriction will run counter to Article 18 ECHR only if the ulterior purpose was predominant, whereas there will be no violation of Article 18 ECHR if the prescribed purpose was the main one, even if the restriction also pursues

3 Jurisprudence up to 31 December 2020 has been taken into account.

4 See e.g. ECtHR, Judgment, 30 April 2013, Tymoshenko v Ukraine, Application No. 49872/11, Joint Dissenting Opinion of Judges Jungwiert, Nußberger and Potocki; ECtHR, Decision, 23 February 2016, Navalnyy and Ofitserov $v$ Russia, Application No. 46632/13, 28671/14, Joint Partly Dissenting Opinion of Judges Nicolaou, Keller and Dedov; ECtHR, Judgment, 11 October 2016, Kasparov v Russia, Application No. 53659/07, Partly Dissenting Opinion of Judge Keller; ECtHR, Judgment (GC), 2 February 2017, Navalnyy v Russia, Application No. 29580/12 and 4 more, Joint Partly Dissenting Opinion of Judges López Guerra, Keller and Pastor Vilanova; ECtHR, Judgment, 17 October 2017, Navalnyy v Russia, Application No. 101/15, Joint Partly Dissenting Opinion of Judges Keller and Dedov; ECtHR, Judgment, 16 November 2017, Ilgar Mammadov v Azerbaijan (No. 2), Application No. 919/15, Joint Dissenting Opinion of Judges Nußberger, Tsotsoria, O'Leary and Mits.

5 ECtHR, Judgment (GC), 28 November 2017, Merabishvili v Georgia, Application No. $72508 / 13$.

6 Id., para. 292. 
another purpose. ${ }^{7}$ The question of which purpose is predominant depends on all the circumstances of the particular case ${ }^{8}$ and thus does not lend itself to an abstract discussion like the one in this chapter.

\section{B. Article 18 ECHR - Autonomous Application Linked with Substantive Convention Guarantees}

Article 18 ECHR is titled 'Limitation on use of restrictions on rights' and is found at the very end of the first section of the Convention. It reads:

'The restrictions permitted under this Convention to the said rights and freedoms shall not be applied for any purpose other than those for which they have been prescribed.'

Together with Article 17 ECHR, which prohibits the abuse of rights, Article 18 ECHR serves as an additional safeguard to the 'Rights and freedoms' contained in the first section of the Convention. Both provisions underline that the restriction of rights permitted under the Convention serves a particular purpose and may neither go beyond this purpose nor serve a different one. Hence, limitations of rights are permissible only if they themselves remain within the limits provided for in the Convention. While this might seem evident, Article 18 ECHR goes beyond the obvious. ${ }^{9}$ It seeks to prevent an abuse of restrictions for purposes contrary to the Convention and thus creates an autonomous role for its application ${ }^{10}$.

Article 18 ECHR presupposes the possibility of lawful restrictions of a right. It is therefore long-standing case law of the Court that it cannot be pleaded alone, but only in conjunction with a substantive Convention guarantee, which contains explicit or inherent restrictions. Nonetheless, Article 18 ECHR has - as already mentioned - an independent scope of application. That independence is underlined by the fact that the finding of a violation of Article 18 ECHR does not depend on the outcome of the Court's examination of an alleged breach of the other provision. Article 18

7 Id., para. 305.

8 Id., para. 307.

9 See ECtHR, Judgment (GC), 28 November 2017, Merabishvili v Georgia, Application No. 72508/13, para. 288.

10 See Satzger et al., 'Does Art. 18 ECHR Grant Protection Against Politically Motivated Criminal Proceedings (Part 1) - Rethinking the Interpretation of Art. 18 ECHR Against the Background of New Jurisprudence of the European Court of Human Rights' (2014) 4 EuCLR 91 (109 ff.). 
ECHR can be breached regardless of whether the other article is found to have been breached. ${ }^{11}$ This clearly demonstrates that Article 18 ECHR protects a legal interest separate from that protected by the right it is pleaded in conjunction with. ${ }^{12}$

\section{Development of the Case Law-From Uncertainty to Clarification}

For quite some time the case law of the Court on Article 18 ECHR was rather inconsistent and even a bit unpredictable: the applicable standard of proof varied, the question of how to deal with a plurality of purposes had not been answered and the scope of application was - and still is - unclear. In November 2017, the Grand Chamber clarified some of these aspects in the case of Merabishvili v. Georgia. ${ }^{13}$

The need to clarify the case law did not arise until well into the late nineteen-nineties and early two thousands. After the entry into force of the Convention in 1953, more than five decades passed before the Court found a separate breach of Article 18 ECHR for the first time in 2004. ${ }^{14}$ Between then and December 2020, there have been another 17 cases (19 if one counts Chamber and Grand Chamber judgments separately) in which the Court held that the respondent Government had breached Article 18 ECHR. What is striking - and alarming - is the increase of judgments finding a violation of Article 18 ECHR in recent years, namely since 2016: 15 of the 20 judgments finding a violation of Article 18 ECHR were handed down over the course of four years between March 2016 and December 2020. This of course raises questions, namely whether this is an indicator for the state of democracy - or rather its demise - in Europe.

At the beginning, however, the Court finding violations of Article 18 ECHR by the Convention States remained the exception. After the first

11 ECtHR, Judgment (GC), 28 November 2017, Merabishvili v Georgia, Application No. 72508/13, para. 288; for an example see ECtHR, Judgment, 19 May 2004, Gusinskiy v Russia, Application No. 70276/01, para. 74 and 77.

12 See ECtHR, Judgment, 11 October 2016, Kasparov v Russia, Application No. 53659/07, Partly Dissenting Opinion of Judge Keller, para. 3; ECtHR, Judgment (GC), 2 February 2017, Navalnyy v Russia, Application No. 29580/12 and 4 more, Joint Partly Dissenting Opinion of Judges López Guerra, Keller and Pastor Vilanova, para. 2.

13 ECtHR, Judgment (GC), 28 November 2017, Merabishvili v Georgia, Application No. $72508 / 13$, paras. $264 \mathrm{ff}$.

14 ECtHR, Judgment, 19 May 2004, Gusinskiy v Russia, Application No. 70276/01. 
judgment in May 2004 in the case of Gusinskiy v. Russia ${ }^{15}$ more than three years passed without a judgment finding a violation of Article 18 ECHR. It was not until November 2007 that the Court found that Moldova had breached Article 18 ECHR taken in conjunction with Article 5 ECHR (Cebotari v. Moldova ${ }^{16}$ ).

Then, four years later the number of violation judgments picked up speed. In July 2012 and April 2013, Ukraine was found to have breached Article 18 ECHR in two cases concerning criminal proceedings against former government members: Lutsenko v. Ukraine ${ }^{17}$ and Tymoshenko v. Ukraine. ${ }^{18}$ In May 2014, the Court found that Azerbaijan had breached Article 18 ECHR in the case of Ilgar Mammadov v. Azerbaijan ${ }^{19}$ (the case led to the first judgment of the Court pursuant to Article $46 \$ 4$ ECHR, holding that Azerbaijan had failed to fulfil its obligation under Article $46 \mathbb{} 1$ ECHR of the Convention $\left.{ }^{20}\right)$. Further judgments against Azerbaijan followed in March 2016 (Rasul Jafarov v. Azerbaijann ${ }^{21}$ ) as well as in April (Mammadli v. Azerbaijan ${ }^{22}$ ), in June (Rashad Hasanov et al. v. Azerbaijan ${ }^{23}$ ) and in September 2018 (Aliyev v. Azerbaijan ${ }^{24}$ ). In June 2016, a new state joined the list of Article 18 ECHR violators: a Chamber held that Georgia had breached Article 18 ECHR in the case of Merabishvili v Georgia ${ }^{25}$. Upon referral, the Grand Chamber ${ }^{26}$ confirmed the judgment and - more importantly - provided the much-needed consolidation of the case law al-

15 Ibid.

16 ECtHR, Judgment, 13 November 2007, Cebotari v Moldova, Application No. 35615/06.

17 ECtHR, Judgment, 3 July 2012, Lutsenko v Ukraine, Application No. 6492/11.

18 ECtHR, Judgment, 30 April 2013, Tymoshenko v Ukraine, Application No. 49872/11.

19 ECtHR, Judgment (GC), 22 May 2014, Ilgar Mammadov v Azerbaijan, Application No.15172/13.

20 Ibid.

21 ECtHR, Judgment, 17 March 2016, Rasul Jafarov v Azerbaijan, Application No. 69981/14.

22 ECtHR, Judgment, 19 April 2018, Mammadli v Azerbaijan, Application No. 47145/14.

23 ECtHR, Judgment, 7 June 2018, Rashad Hasanov et al. v Azerbaijan, Application No. $48653 / 13$ and 3 more.

24 ECtHR, Judgment, 20 September 2018, Aliyev v Azerbaijan, Application No. 68762/14, 71200/14.

25 ECtHR, Judgment, 14 June 2016, Merabishvili v Georgia, Application No. 72508/13.

26 ECtHR, Judgment (GC), 28 November 2017, Merabishvili v Georgia, Application No. 72508/13. 
ready mentioned. In November 2018 and April 2019, judgments involving Russia and Turkey were handed down. Two cases concerned the wellknown political activist Navalnyy: the first of them was a Grand Chamber judgment ${ }^{27}$ whereas in the second case ${ }^{28}$ the request for referral submitted by the government was rejected by the Grand Chamber panel in September 2019. ${ }^{29}$ In the case of Selabattin Demirtaş v. Turkey (No. 2), ${ }^{30}$ the Chamber found a violation of Article 18 in November 2018. Upon referral requests of both the government and the applicant, the Grand Chamber delivered its judgment on 22 December 2020, also finding - inter alia - a violation of Article 18 ECHR in conjunction with Article $5 \mathrm{ECHR}^{31}$. In November 2019, February and July 2020, the Court handed down four more judgments against Azerbaijan in the cases of Natig Jafarov v. Azerbaijan ${ }^{32}$, Ibrahimov and Mammadov v. Azerbaijan ${ }^{33}$, Khadija Ismayilova (no. 2) $v$. Azerbaijan ${ }^{34}$ and Yunusova and Yunusov v. Azerbaijan (No. 2) ${ }^{35}$. In addition, in December 2019 the Court held that Turkey once again had violated Article 18 ECHR in the widely discussed case of Kavala $v$. Turkey. ${ }^{36}$

This overview would not be complete without mentioning a few cases in which the applicants raised Article 18 ECHR complaints but in which the Court declined to either examine these complaints or found no breach of this provision. The most prominent are possibly the two Khodorkovskiy

27 ECtHR, Judgment (GC), 15 November 2018, Navalnyy $v$ Russia, Application No. 29580/12 and 4 more.

28 ECtHR, Judgment, 9 April 2019, Navalnyy $v$ Russia (No. 2), Application No. 43734/14.

29 ECtHR, Press Release 308 (2019).

30 ECtHR, Judgment (GC), 20 November 2018, Selahattin Demirtaşv Turkey (No. 2), Application No. 14305/17.

31 ECtHR, Judgment (GC), 22 December 2020, Selahattin Demirtas v Turkey (No. 2), Application No. 14305/17.

32 ECtHR, Judgment, 7 November 2019, Natig Jafarov v Azerbaijan, Application No. 64581/16.

33 ECtHR, Judgment, 13 February 2020, Ibrahimov and Mammadov v Azerbaijan, Application No. 63571/16 and 5 more.

34 ECtHR, Judgment, 27 February 2020, Khadija Ismayilova (No. 2) v Azerbaijan, Application No. 30778/15.

35 ECtHR, Judgment, 16 July 2020, Yunusova and Yunusov v Azerbijan (No. 2), Application No. 68817/14.

36 ECtHR, Judgment, 10 December 2019, Kavala $v$ Turkey, Application No. $28749 / 18$. The request for referral submitted by the Government was rejected by the Grand Chamber panel on 11 May 2020. 
v. Russia ${ }^{37}$ cases and the related Yukos v. Russia ${ }^{38}$ case from 2011 and 2013, respectively. In all three cases, the Court found that the applicants had not put forth sufficient proof that the State had acted in bad faith. In the 2020 judgment of Khodorkovskiy and Lebedev v. Russia (No. 2), ${ }^{39}$ the Court concluded that no separate issue arose under Article 18 in conjunction with Articles 6 and 7 of the Convention and Article 4 of Protocol no. 7. With regard to an alleged breach of Article 18 in conjunction with Article 8 ECHR, the Court found no evidence of an ulterior motive as alleged by the applicants. Furthermore, there are two cases submitted - inter alia - by the political activist Navalnyy which led to judgments in 2016 and 2017.40 In these cases, the Court dismissed the complaint under Article 18 ECHR taken in conjunction with Articles 6 and 7 ECHR as inadmissible ratione materiae. It held that Article 6 and 7 ECHR did not contain any express or implied restrictions that could form the subject of the Court's examination under Article 18 ECHR of the Convention.

This development of the case law not only illustrates the rather alarming state of democracy in Europe but also shows the Court's increasing willingness to apply Article 18 ECHR and thus hold the Convention States responsible for attempts to stifle Convention rights and freedoms. Furthermore, the high number of cases in which Article 18 complaints were raised in recent years offered the Court an opportunity to clarify and consolidate its case law on this Convention provision.

\section{Application of Article 18 in Conjunction with Article 6 - Inconsistency, but Positive Signals}

Despite of the growing body of case law on Article 18 ECHR, questions as to its application remain. One of the issues this chapter wants to focus

37 ECtHR, Judgment, 31 May 2011, Khodorkovskiy $v$ Russia, Application No. 5829/04, paras. 254 ff.; ECtHR, Judgment, 25 July 2013, Khodorkovskiy and Lebedev $v$ Russia, Application No. 11082/06, 13772/05, paras. $897 \mathrm{ff}$.

38 ECtHR, Judgment, 20 September 2011, OAO Neftyanaya Kompaniya Yukos v Russia, Application No. 14902/04, paras. $663 \mathrm{ff}$.

39 ECtHR, Judgment, 14 January 2020, Khodorkovskiy and Lebedev v Russia (No. 2), Application No. 51111/07, 42757/07, paras. $620 \mathrm{ff}$.

40 ECtHR, Judgment, 23 February 2016, Navalnyy and Ofitserov v Russia, Application No. 46632/13, 28671/14, para. 130; ECtHR, Judgment, 17 October 2017, Navalnyy $v$ Russia, Application No. 101/15, paras. 86 ff. 
on is the scope of application of Article 18 ECHR, namely the question whether it can be raised in conjunction with Article 6 of the Convention.

It is not surprising that the most common Article pleaded in conjunction with Article 18 is Article 5 ECHR. The arrest and detention of a person is likely one of the most effective ways to exclude someone from the political forum and from public debate. However, abusing the restrictions permitted under the Convention to other rights can obviously also frustrate the consensus on democracy and the rule of law underlying the Convention. An example is the November 2018 case of Navalnyy $v$ Russia ${ }^{41}$ in which the Grand Chamber found a violation of Article 18 ECHR in conjunction with Articles 5 and 11 ECHR. Another example is the judgment in the case of Aliyev v Azerbaijan ${ }^{42}$ of September 2018 in which the Court found a violation of Article 18 ECHR taken in conjunction with Articles 5 and 8 ECHR of the Convention.

Concerning the applicability of Article 6 ECHR together with Article 18 ECHR, the Court has not yet come to a coherent approach, let alone found a breach of Article 18 ECHR together with Article 6 ECHR. Instead, in the judgments of February 2016 and October 2017 (Navalnyy and Ofitserov v. Russia; Navalnyy v. Russia), the Third Section of the Court dismissed Article 18 ECHR complaints of the civil society activist Navalnyy and others as inadmissible ratione materiae because they had pleaded a violation only in conjunction with Articles 6 and 7 ECHR. Just one month later, in the case of Ilgar Mammodov v. Azerbaijan (No. 2), ${ }^{43}$ the Fifth Section shied away from addressing the very same question, namely whether the applicant can raise an Article 18 ECHR complaint in conjunction with Article 6 ECHR. Instead, referring to the inconsistent case law, the Chamber stated:

Furthermore, the Court observes that the question whether Article 6 of the Convention contains any express or implied restrictions which may form the subject of the Court's examination under Article 18 of the Convention remains open [...]Taking those circumstances into account and having further regard to the submissions of the parties and its findings under Article $6 \mathbb{1} 1$ of the Convention, the Court considers

41 ECtHR, Judgment (GC), 15 November 2018, Navalnyy v Russia, Application No. 29580/12 and 4 more.

42 ECtHR, Judgment (GC), 20 September 2018, Aliyev v Azerbaijan, Application No. 68762/14, 71200/14.

43 ECtHR, Judgment, 16 November 2017, Ilgar Mammadov v Azerbaijan (No. 2), Application No. 919/15, para. 262. 
that there is no need to give a separate ruling on the complaint under Article 18 in the present case. ${ }^{44}$

At first sight, these judgments make for quite a bleak outlook on the relationship of Articles 6 and 18 ECHR. It seems doomed: either the complaint is deemed inadmissible, or it is not examined at all. However, all of these judgments triggered strong separate opinions, ${ }^{45}$ the authors of which pointed out that - as required by the Court's case law - Article 6 ECHR does allow for both explicit and implicit restrictions. ${ }^{46}$ Furthermore, they drew on the drafting history as well as the purpose underlying Article 18 ECHR. One of the separate opinions concludes:

Although the situation in Europe today cannot be compared to that in Europe in 1950, the importance of this Article has not diminished. The right to a fair trial under Article 6 is one of the guarantees with reference to which fundamental abuses by a state may likely manifest themselves. Therefore, trials before a court must never be used for 'ulterior purposes'. This is the conditio sine qua non; the very basis for the idea of 'fair trial' as understood in the Convention. Almost all the other guarantees are futile if this most basic guarantee is called into question or undermined. ${ }^{47}$

In this context, it is worthwhile to take note of the Council of Europe's Commissioner for Human Rights and her December 2018 third party

$44 I d$., paras. 261f.

45 ECtHR, Judgment, 23 February 2016, Navalnyy and Ofitserov v Russia, Application No. 46632/13, 28671/14, Joint Partly Dissenting Opinion of Judges Nicolaou, Keller and Dedov; ECtHR, Judgment, 17 October 2017, Navalnyy v Russia, Application No. 101/15, Joint Partly Dissenting Opinion of Judges Keller and Dedov and Partly Dissenting Opinion of Judge Serghides; ECtHR, Judgment, 16 November 2017, Ilgar Mammadov v Azerbaijan (No. 2), Application No. 919/15, Joint Concurring Opinion of Judges Nußberger, Tsotsoria, O'Leary and Mits.

46 ECtHR, Decision, 23 February 2016, Navalnyy and Ofitserov v Russia, Application No. 46632/13, 28671/14, Joint Partly Dissenting Opinion of Judges Nicolaou, Keller and Dedov, para. 6; Navalnyy v Russia, Application No. 101/15, Joint Partly Dissenting Opinion of judges Keller and Dedov, para. 7, and Partly Dissenting Opinion of Judge Serghides; ECtHR, Judgment, 16 November 2017, Ilgar Mammadov v Azerbaijan (No. 2), Application No. 919/15, Joint Concurring Opinion of Judges Nußberger, Tsotsoria, O’Leary and Mits, para. 12.

47 ECtHR, Judgment, 16 November 2017, Ilgar Mammadov v Azerbaijan (No. 2), Application No. 919/15, Joint Concurring Opinion of Judges Nußberger, Tsotsoria, O'Leary and Mits, para. 16. 
intervention in the case of Kavala v. Turkey. ${ }^{48}$ The Commissioner alleges possible flagrant abuses of the fair trial guarantees of Article 6 ECHR, in particular with respect to the principle of equality of arms, namely decisions to restrict access to the investigation file. She submitted:

A particular worrying pattern reported to the Commissioner, especially for cases which attract political attention [...], is that despite restriction decisions, information from the investigation file seems to be used frequently in smear campaigns against suspects in pro-governmental media. For the Commissioner, this could be an indication that the motivation behind these decisions is the restriction of defence rights of the suspects, rather than the protection of the integrity of the investigation. ${ }^{49}$

Considering the separate opinions as well as the Commissioner's third-party intervention, there may be room for optimism. The next time the Court has to decide on whether Article 18 ECHR is applicable in conjunction with Article 6 ECHR it will hopefully seize the opportunity and acknowledge that there is no basis for excluding Article 6 ECHR from the scope of application of Article 18 ECHR. The Article 46 ECHR judgment in Ilgar Mammadov v. Azerbaijan of 20 May 2019 might possibly already point in this direction. In this judgment, the Grand Chamber found:

It follows that the Court's finding of a violation of Article 18 in conjunction with Article 5 of the Convention in the first Mammadov judgment vitiated any action resulting from the imposition of the charges..$^{50}$

This conclusion undeniably goes beyond the mere finding of an unfair trial. It might signal that restrictions of the fair trial guarantees of Article 6 ECHR can be applied for ulterior purposes and that this provision can thus be pleaded in conjunction with Article 18 ECHR. ${ }^{51}$

48 ECtHR, Judgment, 10 December 2019, Kavala $v$ Turkey, Application No. 28749/18.

$49 \operatorname{CommDH}(2018) 30,20$ December 2018.

50 ECtHR, Judgment (GC), 29 May 2019, Ilgar Mammadov v Azerbaijan, Application No. 15172/13, para. 189 (emphasis added).

51 See Gavron and Remezaite, 'Has the ECtHR in Mammadov 46 (4) opened the door to findings of "bad faith" in trials?', EJIL:Talk!, 4 July 2019, https://www.ejil talk.org/has-the-ecthr-in-mammadov-464-opened-the-door-to-findings-of-bad-faith -in-trials/. 


\section{E. Burden and Standard of Proof}

As regards the question of proof when examining an alleged violation of Article 18 ECHR, a starting point can be the Court's introductory statement when discussing the burden as well as the standard of proof in these cases. The Court usually states that 'the whole structure of the Convention rests on the general assumption that public authorities in the member States act in good faith'.52 According to the Court, this assumption is rebuttable in theory, but difficult to overcome in practice..$^{53}$ Until the Grand Chamber's clarification of the case law in Merabishvili v. Georgia, the Court tended to use varying standards of proof in Article 18 ECHR cases, though the minimum has always been a 'very exacting standard of proof. However, in the Khodorkovskiy cases the Court's approach was stricter. It required not only that the applicants must 'convincingly show' that the state actions were driven by improper motives, it also asked for 'incontrovertible and direct proof', thereby making it essentially impossible to prove bad faith. ${ }^{54}$ The Court again applied this strict approach in a case against Poland in 2012. ${ }^{55}$ However, in the later cases of Ilgar Mammadov ${ }^{56}$ and Rasul Jafarov v. Azerbaijan, ${ }^{57}$ the Court did not refer to the strict standard; it merely required convincing evidence. Unfortunately, there was no explanation for this more lenient approach.

In order to clarify these issues, the Grand Chamber's attempts to consolidate the case law with regard to the burden of proof (I.) and the standard of proof (II.) in Merabishvili v. Georgia will be examined. Then, it will be shown in a comparative analysis that the Court tends to apply these principles as a safeguard against undemocratic tendencies (III.).

52 ECtHR, Judgment, 31 May 2011, Khodorkovskiy $v$ Russia, Application No. 5829/04, para. 255.

53 Ibid.

54 Ibid., Id., 260; ECtHR, Judgment, 25 July 2013, Khodorkovskiy and Lebedev v Russia, Application No. 11082/06, 13772/05, para. 900, 903.

55 ECtHR, Judgment, 18 September 2012, Dochnal $v$ Poland, Application No. 31622/07, para. 116.

56 ECtHR, Judgment, 22 May 2014, Ilgar Mammadov v Azerbaijan, Application No. $15172 / 13$, paras. $138 \mathrm{ff}$.

57 ECtHR, Judgment, 17 March 2016, Rasul Jafarov v Azerbaijan, Application No. 69981/14, paras. $153 \mathrm{ff}$. 


\section{Burden of Proof-Open Questions and Lack of Guidance for Applicants}

With regard to the burden of proof, the Grand Chamber's findings in $\mathrm{Me}$ rabishvili v. Georgia are regrettably very limited. The Court only reiterated that

as a general rule, the burden of proof is not borne by one or the other party because the Court examines all material before it irrespective of its origin, and because it can, if necessary, obtain material of its own motion. ${ }^{58}$

This leaves unanswered the question of whether the burden of proof can shift to the respondent Government once the applicant has established a prima facie case of improper motive - an interpretation the Chamber expressly refused to follow in the Khodorkovskiy judgment. ${ }^{59}$ If one accepts that the Grand Chamber rubberstamped this Khodorkovskiy line of argument and the burden of proof does not shift to the respondent State, there is still the question of the 'onus of presentation' (Darlegungslast). This 'onus of presentation' is not always and necessarily identical to the 'burden of proof'. It could be argued that in Article 18 ECHR cases, the State has (at least) a so called 'secondary onus of presentation' (sekundäre Darlegungslast), which obliges the State to address and rebut the allegations of the applicant in a sufficiently substantiated manner. ${ }^{60}$ Such a doctrine exists e.g. in German civil procedural law. ${ }^{61}$

It is not clear whether the Grand Chamber in Merabishvili condoned such an obligation and hence a secondary onus of presentation of the respondent State. The statement that the Court can draw inferences from the respondent Government's conduct in the proceedings and may combine such inferences with contextual factors are open for such an inter-

58 ECtHR, Judgment (GC), 28 November 2017, Merabishvili v Georgia, Application No. $72508 / 13$, para. 311.

59 ECtHR, Judgment, 31 May 2011, Khodorkovskiy $v$ Russia, Application No. 5829/04, para. 257; Satzger et al., 'Does Art. 18 ECHR Grant Protection Against Politically Motivated Criminal Proceedings (Part 2) - Prerequisites, Questions of Evidence and Scope of Application' (2014) 4 EuCLR, 248 (253).

60 This is also what Satzger et al. most likely mean when they talk about a shifting of the burden of proof, see 'Does Art. 18 ECHR Grant Protection Against Politically Motivated Criminal Proceedings (Part 2) - Prerequisites, Questions of Evidence and Scope of Application' (2014) 4 EuCLR 248 (255).

61 See e.g. BGH 12.5.2010, NJW 2010, 2061; Fritsche in: Rauscher/Krüger, Münchner Kommentar ZPO I (2020) $₫ 138$ mn. 24. 
pretation. ${ }^{62}$ In addition, the Court referred to situations in which the respondent State alone had access to information capable of corroborating or refuting the applicant's allegations. ${ }^{63}$ This will usually be the case in Article 18 ECHR cases. These vague and elusive rules give the Court certain flexibility in dealing with the individual cases; such flexibility will often be necessary to address particulars of individual cases. However, the standards formulated by the Court in this respect lack sufficient guidance for applicants - and respondent governments for that matter - when arguing Article 18 ECHR cases.

\section{Standard of Proof - The Usual Approach}

As regards the 'standard of proof' in Article 18 cases, the Grand Chamber has put an end to the different approaches. It decided to adhere to its usual approach regarding proof rather than to develop special rules. ${ }^{64}$ Hence, the standard of proof is officially that of 'beyond a reasonable doubt'. ${ }^{65}$ However, the application of this standard depends on the facts in question and the Convention right at stake. ${ }^{66}$ Finally, in assessing the evidence, the Court is not bound by predetermined formulae for its assessment of the evidence; rather, its conclusion is based on a free evaluation of all evidence put before it. ${ }^{67}$ Thus, the Court remains sensitive to any potential evidentiary difficulties encountered by a party. ${ }^{68}$ Therefore, the Court will - like national courts - base its findings on a free evaluation of all evidence.

62 ECtHR, Judgment (GC), 28 November 2017, Merabishvili v Georgia, Application No. $72508 / 13$, para. 312 .

63 Id., para. 313.

$64 I d$., para. 310.

$65 I d$., para. 314.

66 Id., para. 314.

67 ECtHR, Judgment (GC), 6 July 2005, Nachova et al v Bulgaria, Application No. 43577/98 et al, para. 147.

68 ECtHR, Judgment (GC), 28 November 2017, Merabishvili v Georgia, Application No. $72508 / 13$, para. 315 . 


\section{Application of these Principles - A Safeguard against Undemocratic Tendencies}

When looking at the application of these principles in the case law of the Court, there is something worth pointing out: the Court has repeatedly (and rightly) stated that 'high political status does not grant immunity'.69 However, all cases in which there was no direct proof of bad faith and the applicants successfully convinced the Court that the contextual evidence produced was sufficient had been brought by either former members or heads of government (Lutsenko v. Ukraine; Tymoshenko v. Ukraine; Merabishvili v. Georgia) and opposition politicians (Selahattin Demirtaş v. Turkey [No.2]) or civil society activists (Ilgar Mammadov v. Azerbaijan; Rasul Jafarov v. Azerbaijan; Mammadli v. Azerbaijan; Rashad Hasanov and others $v$. Azerbaijan; Navalnyy v. Russia; Yunusova and Yunusov v. Azerbaijan [No. 2]), including human rights lawyers (Aliyev v. Azerbaijan). There are only two violation judgments in cases of applicants who were more into business than into politics. In these cases - Gusinskiy v. Russia and Cebotary v. Moldova - the applicants could advance more or less direct proof of bad faith of the respondent Government.

On the other hand, two other businesspersons did not succeed in convincing the Court to find a violation of Article 18 ECHR. The former heads of the Yukos Company Khodorkovskiy and Lebedev raised Article 18 ECHR complaints to no avail. The Court argued inter alia that 'none of the accusations against them concerned their political activities stricto sensu, even remotely. The applicants were not opposition leaders or public officials' ${ }^{70}$

If this is more than mere coincidence, it suggests that the Court's scrutiny with regard to the standard of proof is less exacting when it comes to applications of political activists, members of the opposition or former government members. This illustrates that Article 18 ECHR as interpreted by the Court has become a safeguard against undemocratic tendencies ${ }^{71}$ as

69 ECtHR, Judgment, 31 May 2011, Khodorkovskiy v Russia, Application No. 5829/04, para. 258.

70 ECtHR, Judgment, 25 July 2013, Khodorkovskiy and Lebedev v Russia, Application No. 11082/06, 13772/05, para. 906.

71 See Keller and Heri, 'Selective criminal proceedings and article 18 ECHR: The European Court of Human Right's untapped potential to protect democracy' (2016) HRLJ 1. 
intended by the drafters of the Convention. ${ }^{72}$ The partly dissenting opinion of judges López Guerra, Keller and Pastor Vilanova in the February 2017 Navalnyy judgment against Russia confirms this assumption. ${ }^{73}$ The dissenting judges summarise the intention behind Article 18 as serving 'to address the abusive limitation of the rights of oppositional actors with the aim of silencing them ${ }^{174}$.

\section{F. Non-Examination of Article 18 - Missed Chances to 'Raise the Red Flag'}

Finally, there is another problem, which has also been the issue of separate opinions, ${ }^{75}$ namely the Court's practice to occasionally abstain from examining the complaint under Article 18 ECHR separately. Two issues as to this practice need to be distinguished.

Sometimes the judgment lacks clear reasoning due to the refusal to separately examine the Article 18 ECHR complaint. ${ }^{76}$ This practice is unsatisfactory because it leaves the reader puzzling as to the possible reasons for the non-examination and might easily appear arbitrary. Of course, a variety of plausible reasons come to mind, like a divided Chamber or a reluctance to relinquish jurisdiction to the Grand Chamber because of the inherent delay caused by such a referral. ${ }^{77}$ For the sake of transparency and coherency of the case law, however, this practice should remain an excep-

72 Teitgen, Rapporteur, First Session of the Consultative Assembly, plenary sitting on 7 September 1949, cited according to $\mathrm{CDH}$ (75) 11, p. 3 [information document prepared by the Registry]; Teitgen, Rapporteur, Second Session of the Consultative Assembly, sitting on 16 August 1950, cited according to $\mathrm{CDH}$ (75) 11, p 9 [information document prepared by the Registry]; ECtHR, Judgment (GC), 28 November 2017, Merabishvili v Georgia, Application No. 72508/13, para. 154.

73 ECtHR, Judgment (GC), 2 February 2017, Navalnyy v Russia, Application No. 29580/12 and 4 more.

74 Id., Joint Partly Dissenting Opinion of Judges López Guerra, Keller and Pastor Vilanova, para. 3.

75 E.g. ECtHR, Judgment, 21 June 2016, Tchankotadze v Georgia, Application No. 15256/05, Dissenting Opinion of Judge Küris, para. $23 \mathrm{ff}$.

76 E.g. ECtHR, Judgment, 16 November 2017, Ilgar Mammadov v Azerbaijan (No. 2), Application No. 919/15, para. 262; for a critique of this practice see also ECtHR, Judgment, 21 June 2016, Tchankotadze v Georgia, Application No. 15256/05, Dissenting Opinion of Judge Kuris, paras. $23 \mathrm{ff}$.

77 See ECtHR, Judgment, 16 November 2017, Ilgar Mammadov v Azerbaijan (No. 2), Application No. 919/15, Joint Dissenting Opinion of Judges Nußberger, Tsotsoria, O'Leary and Mits. 
tion. Rather, the Court should decline a separate examination of Article 18 ECHR only if the complaint is manifestly ill-founded, in particular if there is no interference with the Convention right pleaded in conjunction with Article 18 ECHR. If the act or omission by the respondent State does not even fall within the scope of protection of the Convention right or if there is at least no interference with the right, restrictions permitted under the Convention cannot have been abused. ${ }^{78}$

In other cases, the Court has argued that the Article 18 ECHR complaint raised the same issue that had already been dealt with in connection with a substantive Article of the Convention. ${ }^{79}$ This practice raises even more concerns ${ }^{80}$ because it suggests that the character of Article 18 ECHR is redundant. ${ }^{81}$ It makes an enormous difference whether a judgment 'only' finds a violation of - for example - Article 5 ECHR or whether it also explicitly - establishes a violation of Article 18 ECHR.

In Merabishvili the Grand Chamber required the Article 18 ECHR complaint to be 'a fundamental aspect of the case' to warrant separate examination. ${ }^{82}$ This means that if the circumstances of the case clearly point to a breach of Article 18 ECHR, the Court must, in accordance with its own case law, examine this complaint separately. Only this interpretation is in conformity with the Convention. The refusal of the Court to examine and possibly find a violation of Article 18 ECHR in such cases is detrimental to the spirit of the Convention. A breach of Article 18 ECHR signals to the community of Convention States that there has not only been an 'ordinary' violation of a Convention guarantee..$^{83}$ The finding of a violation of Article 18 ECHR raises the red flag; it highlights that the respondent

78 See Steiger in: Pabel/Schmahl (eds), Internationaler Kommentar zur Europäischen Menschenrechtskonvention (2014), Art. $18 \mathrm{mn} .54 \mathrm{f}$.

79 E.g. ECtHR, Judgment, 18 December 1986, Bozano v France, Application No. 9990/82, para. 61; ECtHR, Judgment, 11 October 2016, Kasparov v Russia, Application No. 53659/07, para. 74 with further references; ECtHR, Judgment (GC), 2 February 2017, Navalnyy $v$ Russia, Application No. 29580/12 and 4 more, para. 79.

80 See also Keller and Heri, 'Selective criminal proceedings and article 18 ECHR: The European Court of Human Right's untapped potential to protect democracy' (2016) HRLJ 1 (8).

81 See Steiger in: Pabel/Schmahl (eds), Internationaler Kommentar zur Europäischen Menschenrechtskonvention (2014), Art. $18 \mathrm{mn} .57 \mathrm{f}$.

82 ECtHR, Judgment (GC), 28 November 2017, Merabishviliv Georgia, Application No. 72508/13, para. 291.

83 Satzger et al., 'Does Art. 18 ECHR Grant Protection Against Politically Motivated Criminal Proceedings (Part 2) - Prerequisites, Questions of Evidence and Scope of Application' (2014) 4 EuCLR 249 (251). 
State has deliberately acted against the presumption that public authorities in the member States act in good faith and in so doing has intentionally damaged the foundation of trust underlying the Convention structure.$^{84} \mathrm{It}$ is only when the Court clearly identifies and sanctions ${ }^{85}$ such violations that it will sound the alarm for the state of democracy and the rule of law in Europe. Only then will it truly live up to its role as the 'Conscience of Europe'. ${ }^{86}$

\section{G. Conclusion - A Developing Tool in Need of Sharpening}

As this chapter has shown, the Court has had ample opportunity in recent years to refine its case law on Article 18 ECHR. And it has used this opportunity, not only to consolidate and clarify the case law but also to reshape Article 18 ECHR into a more effective tool against undemocratic tendencies in a growing number of Convention States.

This chapter has also illustrated, however, that there are issues surrounding the application of Article 18 ECHR that still need to be addressed and resolved. The most pressing among them is the applicability of Article 18 in conjunction with Article 6 ECHR. It is time for the Court to acknowledge that there is no basis for excluding Article 6 from the scope of application of Article 18 ECHR. Regarding the burden of proof in Article 18 ECHR cases, it would be helpful for both applicants and respondent States if the Court gave a clear indication that it will look to the government for a rebuttal if the applicant's allegations regarding the Article 18 ECHR complaint are sufficiently substantiated. Finally, the refusal to conduct a separate examination of an Article 18 ECHR complaint should be handled

84 ECtHR, Judgment, 31 May 2011, Khodorkovskiy v Russia, Application No. 5829/04, para. 255; see Satzger et al., 'Does Art. 18 ECHR Grant Protection Against Politically Motivated Criminal Proceedings (Part 1) - Rethinking the Interpretation of Art. 18 ECHR Against the Background of New Jurisprudence of the European Court of Human Rights' (2014) EuCLR 91 (112).

85 Satzger et al, 'Does Art. 18 ECHR Grant Protection Against Politically Motivated Criminal Proceedings (Part 1) - Rethinking the Interpretation of Art. 18 ECHR Against the Background of New Jurisprudence of the European Court of Human Rights' (2014) EuCLR 91 (112).

86 Council of Europe, The Conscience of Europe: 50 Years of the European Court of Human Rights (2010); cf. also Dzehtsiarou and Tzevelekos, 'The Conscience of Europe that Landed in Strasbourg: A Circle of Life of the European Court of Human Rights' (2020) 1 ECHR law review 1. 
with care and restraint. The Court should only choose this path if the Article 18 ECHR complaint is manifestly ill-founded. ${ }^{87}$

Clarification of these issues will enhance the value of Article 18 ECHR in the practice of the Court and might transform this newly discovered tool into a sharp and effective instrument for the protection of democracy in Europe.

\section{Bibliography}

Bershidsky, Leonid: Putin reminds Russians he can do suppression. A record crackdown on protests in Moscow is a warning to voters tempted to protest their increasingly hopeless situation, Bloomberg L.P., 29 July 2019, https://www.bloo mberg.com/opinion/articles/2019-07-29/moscow-protests-vladimir-putin-s-suppr ession-potential.

Bigalke, Silke: Mit aller Macht. Bei Protesten in Moskau wurden am Samstag mehr als 1000 Menschen festgenommen - sie forderten die Zulassung von Oppositionskandidaten zur Stadtratswahl. Um die Politiker selbst hatten sich die Behörden bereits gekümmert. Süddeutsche Zeitung, 28 July 2019, https://w ww.sueddeutsche.de/politik/russland-mit-aller-macht-1.4542891.

Dzehtsiarou, Kanstantsin/Tzevelekos, Vassilis: The Conscience of Europe that Landed in Strasbourg: A Circle of Life of the European Court of Human Rights, ECHR law review 2020, $1 \mathrm{ff}$.

Fritsche in: Rauscher/Krüger, Münchner Kommentar ZPO I (2020).

Gavron, Jessica/Remezaite, Ramute: Has the ECtHR in Mammadov 46(4) opened the door to findings of 'bad faith' in trials?, EJIL:Talk!, 4 July 2019, https://www .ejiltalk.org/has-the-ecthr-in-mammadov-464-opened-the-door-to-findings-of-bad -faith-in-trials/.

Keller, Helen/Heri, Corina: Selective criminal proceedings and article 18 ECHR: The European Court of Human Right's untapped potential to protect democracy, HRLJ 2016, $1 \mathrm{ff}$.

Satzger, Helmut/Zimmermann, Frank/Eibach, Martin: Does Art. 18 ECHR Grant Protection Against Politically Motivated Criminal Proceedings (Part 1) - Rethinking the Interpretation of Art. 18 ECHR Against the Background of New Jurisprudence of the European Court of Human Rights, EuCLR 2014, $91 \mathrm{ff}$.

Satzger, Helmut/Zimmermann, Frank/Eibach, Martin: Does Art. 18 ECHR Grant Protection Against Politically Motivated Criminal Proceedings (Part 2) - Prerequisites, Questions of Evidence and Scope of Application, EuCLR 2014, $248 \mathrm{ff}$.

Steiger, Dominik, in: Pabel, Katharina/Schmahl, Stefanie (eds), Internationaler Kommentar zur Europäischen Menschenrechtskonvention (2014), Art. 18.

87 For an example see ECtHR, Decision, 12 January 2021, Rarinca v Romania, Application No. 10003/16, para $135 \mathrm{f}$. 
Teitgen, Rapporteur: First Session of the Consultative Assembly, plenary sitting on 7 September 1949, CDH (75) 11, 3.

Teitgen, Rapporteur: Second Session of the Consultative Assembly, sitting on 16 August 1950, CDH (75) 11. 
